S.Yu. Shevchenko, N.A. Savchenko, A.V. Tretjak

\title{
MANAGING THE LOAD SCHEDULE OF THE ADMINISTRATIVE BUILDING TAKING INTO ACCOUNT EMERGING RISKS WHEN CONNECTING THE KINETIC ENERGY STORAGE TO THE POWER SUPPLY SYSTEM
}

Purpose. The purpose of the paper is to analyze load schedules of the administrative building and develop a structural scheme for connecting the kinetic energy storage in the power supply system of this building, which will allow using it as a consumer regulator, as well as a theoretical study of the risks that arise. Methodology. To conduct the research, the theory of designing internal electrical networks of buildings, the theory of plotting electric load graphs, methods of the theory of electromechanical systems and for analyzing the risk system, the T. Saati method of hierarchies were used. Results. The structure of kinetic energy storage (KES) connection to the power supply system of the administrative building is developed and the structural diagram of the KES proposed for installation is given, the average daily winter and summer load schedules are presented, a set of groups and subgroups of risks and their influence on the work of the power supply system of the building are connected with the connection of the KES. Originality. For the first time, the application of the kinetic energy storage in the power supply system of the building with the analysis of emerging risks is considered, which makes it possible to improve the reliability of the developed system and the efficiency of load regulation. Practical value. The application of the proposed scheme will make it possible to use administrative buildings as load regulators of the external power supply system, and also effectively manage the load in the internal power supply system of the building. References 9, tables 2, figures 4.

Key words: power supply system, kinetic energy storage (KES), electric load schedule, risk system, consumer regulator.

Цель. Целью статьи является разработка структурной схемы подключения кинетического энергонакопителя в систему электроснабжения административного здания, что позволит использовать это здание в качестве потребителя - регулятора, а такюе теоретическое исследование возникающих при этом рисков. Методика. Для проведения исследований использовались теория проектирования внутренних электрических сетей зданий, теория построения графиков электрической нагрузи, методы теории электромеханических систем и для анализа системы рисков метод иерархий T. Саати. Результаты. Разработана структура подключения кинетического энергонакопителя (КЭН) в систему электроснабжения административного здания и приведены суточные графики нагрузок, исследован набор групп и подгрупп рисков и их влияние на работу системы электроснабжения здания при подключении КЭН. Научная новизна. Впервые рассмотрено применение кинетического энергонакопителя в системе электроснабжения здания с анализом возникающих рисков, что позволяет повысить надежность работы разработанной системы и эффективность регулирования нагрузки. Практическое значение. Применение предложенной схемы позволит использовать административные здания в качестве регуляторов нагрузки внешней системы электроснабжения, а также эффективно управлять нагрузкой во внутренней системе электроснабжения здания. Библ. 9, табл. 2, рис. 4.

Ключевые слова: система электроснабжения, кинетический энергонакопитель (КЭН), график электрической нагрузки, система рисков, потребитель-регулятор.

Introduction. The problem of covering non-uniform electric load schedules is currently being solved by three main methods [1]:

- creation of an optimal structure of generating capacities in the power system;

- use of overflows with neighboring power systems;

- attracting consumers to align the load schedule.

The Ukrainian power system is not an exception among other energy systems of the world and there is an imbalance in the generation and consumption of electricity. Thus, consumption during peak hours sometimes significantly exceeds generation capacity to cope with loads. To solve the existing problem, the implementation of various storage devices and accumulators in the power supply systems of consumers and the use of these consumers as load regulators in the power system can help.

To date, electrochemical batteries for energy storage which have a significant shortcoming - fragility are widely used. Therefore, at present, as an alternative, many researchers propose the use of kinetic energy storage (KES) [2-6]. This device is intended for the storage of mechanical energy and its further transformation into electrical energy which can be used to regulate the load of the power system as a whole or its individual links.

At the moment, there are developments on the application of KES in autonomous power supply systems of buildings together with alternative energy sources $[5,6]$ and for energy storage in power systems $[2,4,5]$.

Modern KES can store energy up to $20 \mathrm{MJ}$ and produce power of $250-350 \mathrm{~kW}$, while the size of the storage is small, and the efficiency is $85-90 \%$ [9]. Also KES performs additional functions when operating in the customer's network, such as: implementation of a full galvanic isolation from the network, ensuring the quality of power supply, filtering distortion of harmonics and 
voltage peaks, eliminating current micro breakdowns of duration less than $50 \mathrm{~ms}$.

The use of KES for energy storage and load regulation is an important step in improving the energy efficiency of power supply systems. The stored energy can be used during peak hours for regulation purposes in power supply systems for administrative buildings which is attractive from an economic point of view, but this is due to a number of risks. The analysis of the risk system and their minimization is an important factor in improving the reliability of power supply systems.

The goal of the work is development of a structural scheme for connecting the kinetic energy storage to the power supply system of the administrative building to regulate the load of both the building itself and its use as a consumer - the load regulator of the power system as a whole.

Analysis of daily schedules of the administrative building (the 1st educational building of the Donbass National Academy of Construction and Architecture (DonNACA)). Daily schedules are necessary to record changes and obtain visual information about periods of peak load. They contain the information obtained on a certain day of the month and the season of the year. As the investigated object, the DonNACA educational building with a total area of $2,250 \mathrm{~m}^{2}$ is considered, which includes classrooms and laboratories, a rector's office, a public catering enterprise equipped with electric cookers.

Daily fluctuations in consumption schedules and seasonal fluctuations are largely determined by meteorological factors: ambient air temperature, illumination, humidity, wind speed [7].

Analysis of the dynamics of electricity consumption shows (Fig. 1) that with increasing temperature and increasing illumination in summer, energy consumption is reduced [7]. As can be seen from the schedules, in the winter and summer for the object under study, we have the morning maximum load. The peak load falls on the period from 7.00 am to $2.00 \mathrm{pm}$. The minimum load is observed in the evening and at night between $6 \mathrm{pm}$ and 7 am.

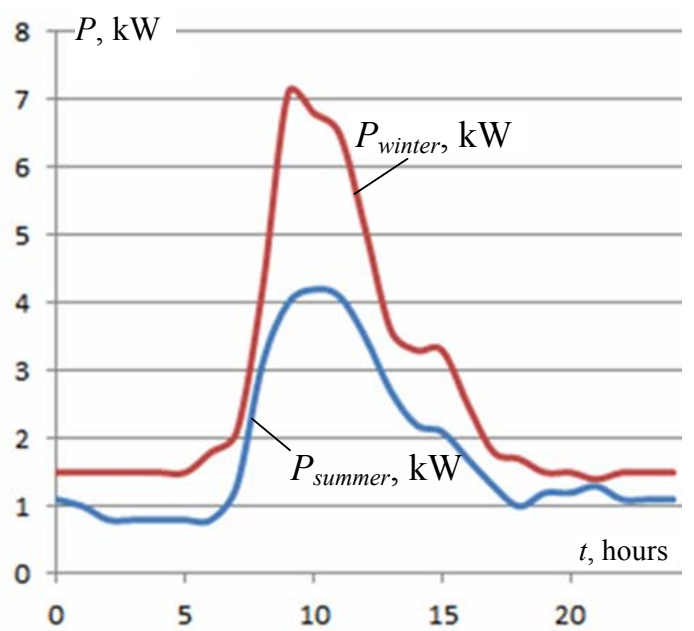

Fig. 1. Average daily load schedules of summer $\left(P_{\text {summer }}\right)$ and winter $\left(P_{\text {winter }}\right)$ days for the educational building
The connection of a KES to the power supply system of the building will give an opportunity to regulate (equalize) the load schedule of the building, namely, during the hours of load decay the KES will operate as an electric power consumer, and at peak hours as a generator that will allow the building to be used as a consumer load regulator.

The scheme of connecting the KES to the power supply system of the administrative building. The developed structural scheme of connecting the KES to the power supply system of the administrative building, presented in Fig. 2, consists of a control unit $(\mathrm{CU})$, kinetic energy storage (KES), load sensor (S), and inverter (I).

The operation is carried out as follows. At low load of the building, the value of which is controlled by the load sensor installed on the building supply line, automatic charging of the KES takes place. With increasing load in the building, the control unit (CU) switches the inverter to the generation mode synchronously with the network, feeding the building, after the load is reduced, the inverter turns off and the KES charging is performed.

Standard current transformers (CT) installed in the input node of electricity metering can serve as a current sensor. As a control unit (CU), you can use a programmable logic controller (PLC) with several analog inputs and outputs. If you need to connect to energy storage systems in other buildings or regional power system, you can use a controller with an Ethernet control channel.

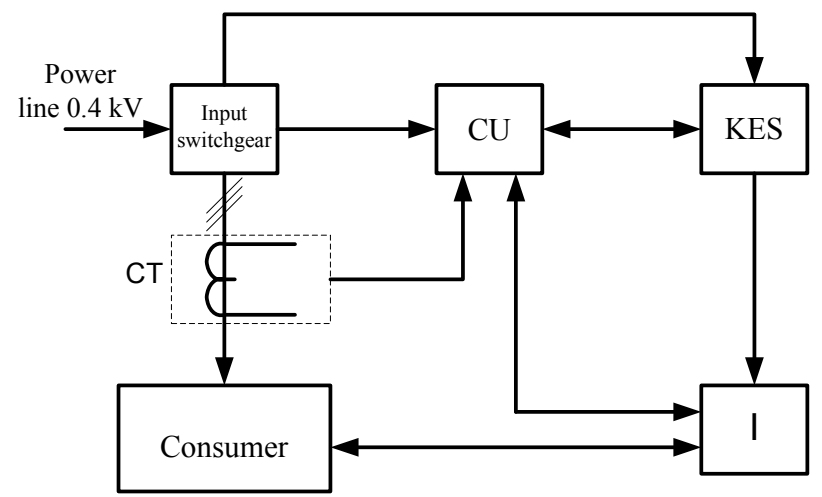

Fig. 2. The structural scheme of connecting the KES to the power supply system of the building

The KES consists of a storage flywheel (Fig. 3), a charging system motor $M$ and a generator $G$, it is also possible to use a charging motor as a generator, but with a complicated switching system.

The power of the generator and the storage capacity of the flywheel are selected based on the value of the building's load. The charging system of the KES consists of an electric motor and a frequency converter (FC) operating in a closed system (with feedback). If it is necessary to charge the KES, the CU supplies the corresponding FC signal for start-up and the flywheel is accelerated with the set acceleration time parameters. 
After the flywheel is completely accelerated, the FC maintains its stable rotation through feedback.

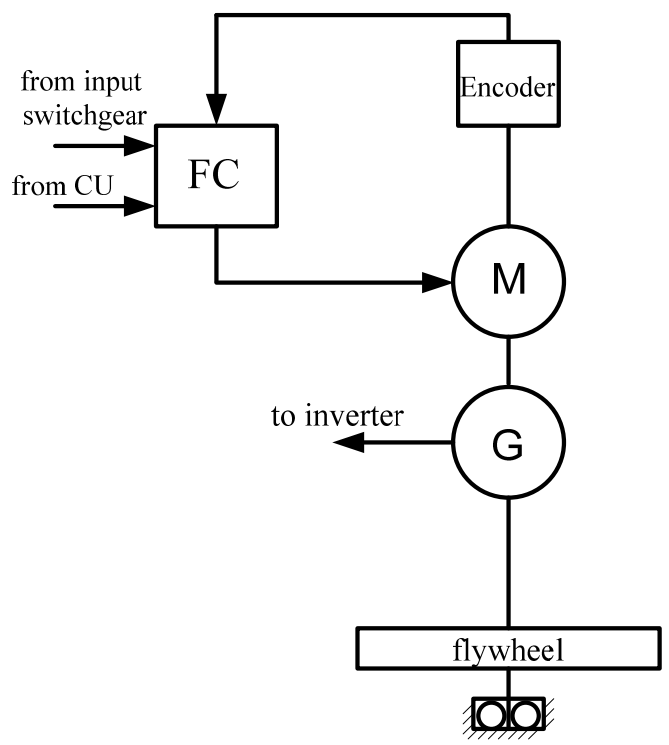

Fig. 3. The KES structural scheme

The charging motor of the KES and its FC is advisable to use of significantly less power than the generator, because charging takes a much longer time than discharge. This will reduce the price of the structure as a whole. The flywheel should be installed in a specially equipped pit near the building.

With increasing load in the building, the CU issues a command to the inverter (I) for the start, which, in turn, instructs the FC to stop feeding the KES. When the speed of the KES flywheel is reduced to a critical one, or the power consumption in the building is reduced, the inverter turns off automatically and, if possible, recharges the KES.

In order to increase the reliability and efficiency of the developed scheme of connecting the KES to the power supply system of the building, an analysis was made of the groups and subgroups of risks arising from the functioning of this system.

Analysis of risks in the operation of the power supply system of the building with KES. To determine and investigate common risks in the operation of power supply systems with the KES of administrative buildings, the hierarchy analysis method (HAM) developed by T. Saati was applied.

The hierarchy analysis method (HAM) is used to derive relationship scales from both discrete and continuous paired comparisons in multi-level hierarchical structures.

HAM has specific aspects related to the deviation of judgments from consistency and the measurement of this deviation, as well as the dependence within groups and between groups of elements of a hierarchical structure [8].

When using HAM for modeling, it is necessary to construct a hierarchical or network structure for the representation of the problem, then, pairwise comparing the elements of this structure, to obtain dominance matrices from which the scales of relations are derived.

In general, the hierarchical structure is composed from three levels: the first level - the goal from the point of view of management, the second level - the criteria on which the following levels depend, the third or the lowest level - the list of alternatives (Fig. 4).

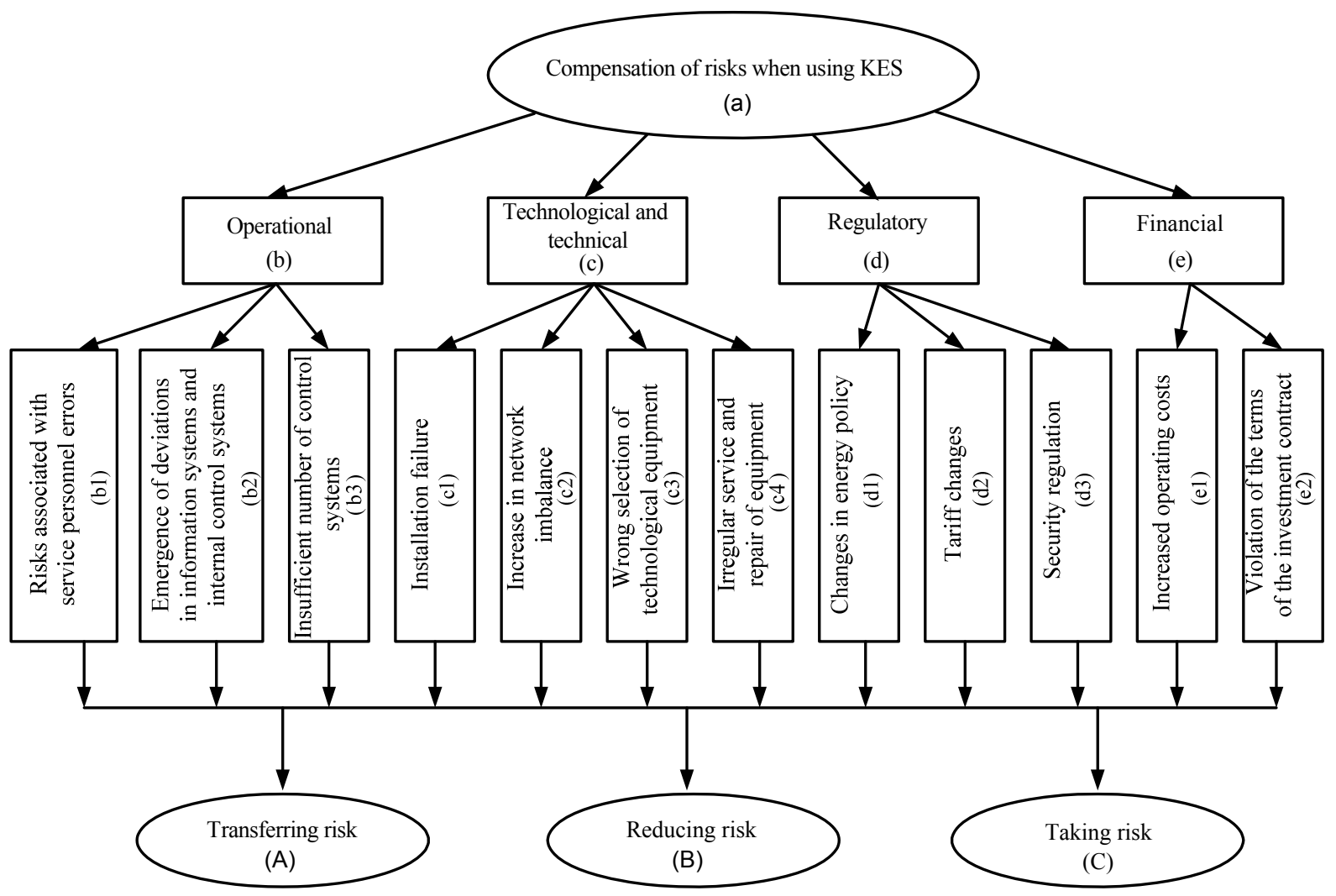

Fig. 4. A model of the hierarchical structure of risk analysis 
The following notation is used in the model:

1. Purpose, or the main criterion (compensation of risks when using KES) - a.

2. Criteria for the first level (risk groups - operational, technological and technical, regulatory, financial) $-\mathrm{b}, \mathrm{c}$, d, e.

3. Criteria of the second level (subgroups of risks of the first level) - b1, b2, b3, c1, c2, c3, c4, d1, d2, d3, e1, e2.

4. Alternatives to achieving the goal (transferring risk, reducing risk, taking risk) $-\mathrm{A}, \mathrm{B}, \mathrm{C}$.

The second stage of the HAM is the compilation of an algorithm for achieving the goal, namely: it is necessary to determine the impact of risk groups on the system as a whole. We use the technique described in [8] which consists in the following: firstly, matrices of pairwise comparisons of intermediate criteria with respect to higher-level criteria are written, for comparison, a scale of relative importance developed by T. Saati [8] is used; secondly, the transition from matched matrices to priority vectors is performed; thirdly, the quality of matrices of pairwise comparisons is checked, or the consistency index is calculated.

Expert data were used to compile the matrix of pairwise comparisons. The results of calculations of the matrix of pairwise comparisons of criteria for the first level of the hierarchy are presented in Table 1 . In the same way, comparisons are made for the second level of the hierarchy.

Table 1

Determination of the most important risk group with a view to their compensation

\begin{tabular}{|c|c|c|c|c|c|c|}
\hline Risk group & 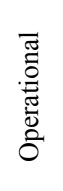 & 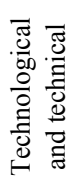 & 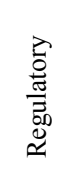 & 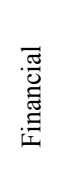 & 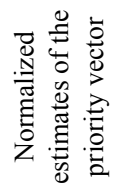 & 䒕 \\
\hline Operational & 1 & $1 / 3$ & 4 & 1 & 0.2164 & 2 \\
\hline $\begin{array}{l}\text { Technological and } \\
\text { technical }\end{array}$ & 3 & 1 & 5 & 3 & 0.5216 & 1 \\
\hline Regulatory & $1 / 4$ & $1 / 5$ & 1 & $1 / 2$ & 0.0801 & 4 \\
\hline Financial & 1 & $1 / 3$ & 2 & 1 & 0.1820 & 3 \\
\hline Total & 5.25 & 1.86 & 12.00 & 5.50 & & \\
\hline \multicolumn{7}{|c|}{ Consistency index $\mathrm{CI}=0,024$} \\
\hline \multicolumn{7}{|c|}{ Consistency relation $\mathrm{CR}=0.027=2.7 \%$} \\
\hline
\end{tabular}

According to the calculations, we have $\mathrm{CR}=0.027 \leq 0.1$ which allows us to conclude that the assessments of experts in the matrix are consistent and do not need revision.

The main result of pairwise comparisons is the determination of the importance of alternatives which are given in Table 2.

Based on the results of the calculations, we have the highest estimation of 0.4427 for the alternative «reducing risk» - this is an opportunity to reduce the consequences of the occurrence of risks. Risks that can not be reduced or transferred are in second place and have the estimation of 0.3458 . Risks that can partially be compensated by transfer to the second responsible persons have the lowest estimation -0.2115 .

Table 2

Determination of the importance of alternatives

\begin{tabular}{|l|c|c|}
\hline \multicolumn{1}{|c|}{ Alternative } & $\begin{array}{c}\text { Assessment of the importance of } \\
\text { the alternative }\end{array}$ & Rang \\
\hline $\begin{array}{l}\text { Transferring } \\
\text { risk }\end{array}$ & 0.2115 & 3 \\
\hline Reducing risk & 0.4427 & 1 \\
\hline Taking risk & 0.3458 & 2 \\
\hline
\end{tabular}

The performed analysis of the risk system shows that in order to increase the reliability and efficiency of the power supply system of a building with a connected $\mathrm{KES}$, it is necessary to perform a number of administrative and technical measures to reduce technological, technical and operational risks, financial risks may be partially transferred to third parties (investors and insurance companies), and regulatory risks should be taken into account, as the impact on them is completely absent.

\section{Conclusions.}

1. The schedules of the load of a real building are given and analyzed. On the basis of the analysis, a method for regulating the load of a building and its simultaneous use as a consumer regulator is defined.

2. The structural scheme of connection of the kinetic energy storage to the power supply system of the building is developed which increases the efficiency of its operation and allows to regulate the load.

3. The analysis of the risk system at the use of kinetic energy storage in the building energy supply systems is carried out which will allow to minimize them and provide increased reliability of the power supply system.

\section{REFERENCES}

1. Gurtovtsev A.L., Zabello E.P. Electrical load of the power system. Aligning the schedule. Electrical engineering news, 2008, no.5(53). Available at: http://www.news.elteh.ru/arh/2008/53/19.php (Accessed 12 May 2017). (Rus).

2. Daoud M.I., Abdel-Khalik A.S., Massoud A., Ahmed S., Abbasy N.H. On the development of flywheel storage systems for power system applications: a survey. 2012 XXth International Conference on Electrical Machines, Marseille, France, 2-5 September 2012, pp. 2119-2125. doi: 10.1109/icelmach.2012.6350175.

3. Yali Y., Yuanxi W., Feng S. The latest development of the motor/generator for the flywheel energy storage system. 2011 International Conference on Mechatronic Science, Electric Engineering and Computer (MEC), Jilin, China, 1922 August 2011, pp. 1228-1232. doi: 10.1109/mec.2011.6025689.

4. Babuska V., Beatty S.M., deBlonk B.J., Fausz J.L. A review of technology developments in flywheel attitude control and energy transmission systems. 2004 IEEE Aerospace Conference Proceedings (IEEE Cat. No.04TH8720), Big Sky, MT, USA, 613 March 2004, pp. 2784-2800. doi: 10.1109/aero.2004.1368076. 
5. Chen H., Cong T.N., Yang W., Tan C., Li Y., Ding Y. Progress in electrical energy storage system: A critical review. Progress in Natural Science, 2009, vol.19, no.3, pp. 291-312. doi: 10.1016/j.pnsc.2008.07.014.

6. Aljohani T.M. The flywheel energy storage system: a conceptual study, design, and applications in modern power systems. International Journal of Electrical Energy, 2014, vol.2, no.2, pp. 146-153. doi: 10.12720/ijoee.2.2.146-153.

7. Savchenko N.A., Shevchenko S.Yu. Determination of input parameters of the information base for load prognostication in distribution networks 6-10 kV. Electrical networks and systems, 2010, no.3, pp. 9-14. (Rus).

8. Saati T. Priniatie reshenii. Metod analiza ierarkhii [Making decisions. The method of analyzing hierarchies]. Moscow, Radio and Communication Publ., 1993. 278 p. (Rus).

9. Available at: http://www.atz gmbh.com/Products/HTS bearing/Flywheel/body flywheel.htm (accessed 15 September 2017).
S.Yu. Shevchenko ${ }^{1}$, Doctor of Technical Science, Professor, N.A. Savchenko ${ }^{2}$, Postgraduate Student,

A.V. Tretjak ${ }^{2}$, Postgraduate Student,

${ }^{1}$ National Technical University «Kharkiv Polytechnic Institute», 2, Kyrpychova Str., Kharkiv, 61002, Ukraine, phone +380 577076312 ,

e-mail: syurik42@gmail.com

${ }^{2}$ Donbas National Academy of Civil Engineering and Architecture,

14, Geroev Nebesnoi Sotni Str., Kramatorsk, Donetsk region, 84333, Ukraine,

phone +38062 6461999,

e-mail: natali_a_savchenko@ukr.net, tretjak_a.v@ukr.net

Received 20.10.2017

How to cite this article:

Shevchenko S.Yu., Savchenko N.A., Tretjak A.V. Managing the load schedule of the administrative building taking into account emerging risks when connecting the kinetic energy storage to the power supply system. Electrical engineering \& electromechanics, 2017, no.6, pp. 69-73. doi: 10.20998/2074-272X.2017.6.11. 